\title{
ニッケルホウ化物の電子照射誘起アモルファス化
}

\author{
坂田孝夫・森 博太郎・藤田広志 \\ (大阪大学超高圧電子顕微鏡センター, 565 吹田市山田丘)
}

\section{Electron Irradiation Induced Amorphization of Nickel Borides}

\author{
Takao SAKATA, Hirotaro MORI and Hiroshi FUJITA
}

(Research Center for Ultra-High Voltage Electron Microscopy, Osaka University, Yamada-oka, Suita-shi, Osaka

$565)$

The electron irradiation induced crystalline to amorphous $(C-A)$ transition was examined in the Ni-B binary system by ultra-high voltage electron microscopy. The seven equilibrium phases ( $i_{.} e_{.}, \mathrm{Ni}, \mathrm{Ni} \mathrm{i}_{3} \mathrm{~B}, \mathrm{Ni} \mathrm{i}_{\mathbf{2}} \mathrm{B}, \mathrm{o}-\mathrm{Ni} \mathrm{i}_{4} \mathrm{~B}_{3}, \mathrm{~m}-\mathrm{Ni} \mathrm{i}_{3}, \mathrm{NiB}$, and $B$ ) in the system were all irradiated with $2 \mathrm{MeV}$ electrons at a fixed temperature of $4.2 \mathrm{~K}$, and the tendency towards the $\mathrm{C}-\mathrm{A}$ transition has been compared among the phases. Of the seven, only $\mathrm{Ni}_{2} \mathrm{~B}$ and o- $\mathrm{Ni}_{4} \mathrm{~B}_{3}$ compounds undergo a complete $C-A$ transition by the irradiation while the other five do not. Analysis of the results shows that the amorphization tendency under electron irradiation is best correlated with the position of the materials in the corresponding temperature-composition phase diagram. Namely, those compounds whose position in the diagram is close to the bottom of a deep valley of liquidus in the diagram have a strong tendency towards the $C$ - $A$ transition, while those away from such a valley do not exhibit the $C-A$ transition.

[Received October 20, 1988; Accepted December 15, 1988]

Key-words : Nickel boride, Amorphization, Electron irradiation, Radiation effects, Coordination, HVEM

\section{1. 緒言}

近年, 新しい機能を備えた材料を開発する目的で，い わゆる非平衡状態にある物質の創製とその構造ならびに 物性に関する研究が活発に行われている. その典型例の 一つにアモルファス物質の研究があげられる。これまで にアモルファス物質の作製法としては，現在最も一般的 に用いられている液体急冷法の他に，スパッタリングや 化学気相凝縮法などの気相急冷法, 固相-固相反応や固 相一ガス反応を利用する固相反応法, さらには高エネル ギーの粒子線を標的物質に照射する粒子線照射法などが 考案されている. 最近, 著者らのグループは, 超高電圧 電子顕微鏡 (以下電子顕微鏡を電顕と略記) 法を用いて, 高エネルギー電子線の照射効果を利用する新しいアモル ファス作製法を開発した ${ }^{1) \sim 5)}$ 。この方法は，対象とする 結晶をしきい電圧以上の電圧で加速された電子線で照射 して, 各原子を変位させることによってアモルファス化 するものであり，手法の上からは上述の粒子線照射法の 範疇に属する。しかし，この新しい方法においては，導 入される損傷の主な形態は結晶格子久宿の中で最も単純 な形態をとる点欠陥であり, 従来のイオン照射や中性子 照射の場合のようなカスケード損傷は形成されない。こ のカスケード損傷の内部では, 激しく励起された原子の 集団が $10^{-12}$ 秒程度の間に室温に冷却される一種の “急 冷効果” が生じており ${ }^{6)}$, このようなカスケード領域の 重畳によってアモルファス化が生じる場合には，その機 構は本質的に液体急冷法のそれと同一視できる。した
がって, アモルファス化機構の観点からは，この電子線 照射法はむしろ固相反応法に近いと考えることができ る.この電子線照射法においては, 他の固相反応法では 不可能な, 組成の変動を全く伴わない単純条件下での固 相から固相へのアモルファス遷移を実現できる利点があ り，これを活用すれば，その遷移の解析を通して固体内 の原子配列を支配する因子に関する情報やアモルファス 形成の一般法則に対する知見を得ることが可能となる. このような観点から, 著者らのグループでは一連の金属 および非金属化合物を対象としてその電子照射誘起アモ ルファス化に関する系統的な研究を行っている71,8). 本 研究では，ホウ化物セラミックスのアモルファス化に関 する研究の一環として, ニッケルホウ化物の電子照射誘 起アモルファス化能を調べた。すなわち, Ni-B 二元系 に存在するすべての化合物 $\left(\mathrm{Ni}_{3} \mathrm{~B}, \mathrm{Ni}_{2} \mathrm{~B}, \mathrm{O}-\mathrm{Ni}_{4} \mathrm{~B}_{3}, \mathrm{~m}\right.$ $\mathrm{Ni}_{4} \mathrm{~B}_{3}$ および $\mathrm{NiB}$ の 5 個の化合物）ならびに純物質の $\mathrm{Ni}$ と B を試料として選び，それらのアモルファス化能 を超高圧電顕法によって調べるとともに, 得られた結果 を相互に比較・解析した.

\section{2. 実験方法}

\section{1 試 料}

純度 $99.99 \%$ の $\mathrm{Ni}$ と純度 $99.9 \%$ の B を用いて, アーク・メルト法により, Ni-31 at \% B, Ni-42 at \% B および Ni-47 at \% B の三種類の組成の合金を溶製した. 溶解にあたっては，アーク炉内の酸素分圧を低下させる 
目的で，あらかじめジルコニウムを溶解して溶融状態に 300 秒間保持した. 雾囲気ガスとしては 1 気圧の高純度 アルゴンを用い，各合金とも約 5 グラムのボタンを作製 した.これらのボタン状合金に $1173 \mathrm{~K}, 86.4 \mathrm{ks}$ の焼鈍 を施して, Ni-31 at \% B 合金は $\mathrm{Ni}_{3} \mathrm{~B}$ と $\mathrm{Ni}_{2} \mathrm{~B}$ を含む二 相合金に, $\mathrm{Ni}-42$ at \% B 合金は o- $\mathrm{Ni}_{4} \mathrm{~B}_{3}$ の一相合金に, また Ni-47 at \% B 合金は $\mathrm{m}_{-}-\mathrm{Ni}_{4} \mathrm{~B}_{3}$ と $\mathrm{NiB}$ を含む二相合 金にそれぞれ変態させて試料とした．純物質の $\mathrm{Ni}$ と $\mathrm{B}$ についてもそれぞれ約 5 グラムのボタンを溶製して試料 とした. 電顕観察用の薄膜試料は，これらのボタン状試 料を放電加工機もしくは水冷高速カッターにより板状に 切断した後，機械研磨と電解研磨を用いて作製した。機 械研磨は $\mathrm{SiC}$ 研磨紙を用いて，また電解研磨は硝酸， メチルアルコール混液によるジェット研磨と過塩素酸, メチルアルコール混液による仕上げ研磨を併用して，そ れぞれ行った. なお純物質 Bについては，機械研磨後 イオン・シンニング法を用いて薄膜を得た。

\section{2 電子線照射}

電子線照射は日立 HU-3000 型超高圧電顥を用いて, 加速電圧 $2 \mathrm{MV}$, 照射強度 $1.3 \times 10^{24} \mathrm{e} / \mathrm{m}^{2} \mathrm{~s}$ で行い, 照
射の進行に伴う組織亡構造の変化をそれぞれ明視野像と 電子回折図形によってその場観察した．照射には直径約 $2 \mu \mathrm{m}$ の収束ビームを用いた。 また照射温度は，これら の化合物における点欠宿の高い易動度を勘案して $4.2 \mathrm{~K}$ とした。

\section{3. 結 果}

$\mathrm{Ni}-\mathrm{B}$ 系に存在する 5 個の化合物に純物質の $\mathrm{Ni}$ およ び $\mathrm{B}$ を加えた合計 7 種類の相の中で, $\mathrm{Ni}_{2} \mathrm{~B}$ と $-\mathrm{Ni}_{4} \mathrm{~B}_{3}$ は約 2400 秒の照射によって完全にアモルファス化する. 一方, $\mathrm{m}-\mathrm{Ni}_{4} \mathrm{~B}_{3}$ と $\mathrm{NiB}$ では回折図形にアモルファス特 有のいわゆるハローリングが現れるものの, その強度は $10^{4}$ 秒以上の重照射後もなお微弱であり, 完全なアモル

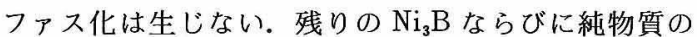
$\mathrm{Ni} お$ よび B は結晶を保つ. 以下にこれらの詳細を順に 示す.

$3.1 \mathrm{Ni}_{2} \mathrm{~B}$ および o- $\mathrm{Ni}_{4} \mathrm{~B}_{3}$ における結晶-アモルファ 又遷移

図 1 は $\mathrm{Ni}_{2} \mathrm{~B}$ におけるアモルファス化過程を連続的に 観察した結果の一例であり，(a)，(b) および（c）は，
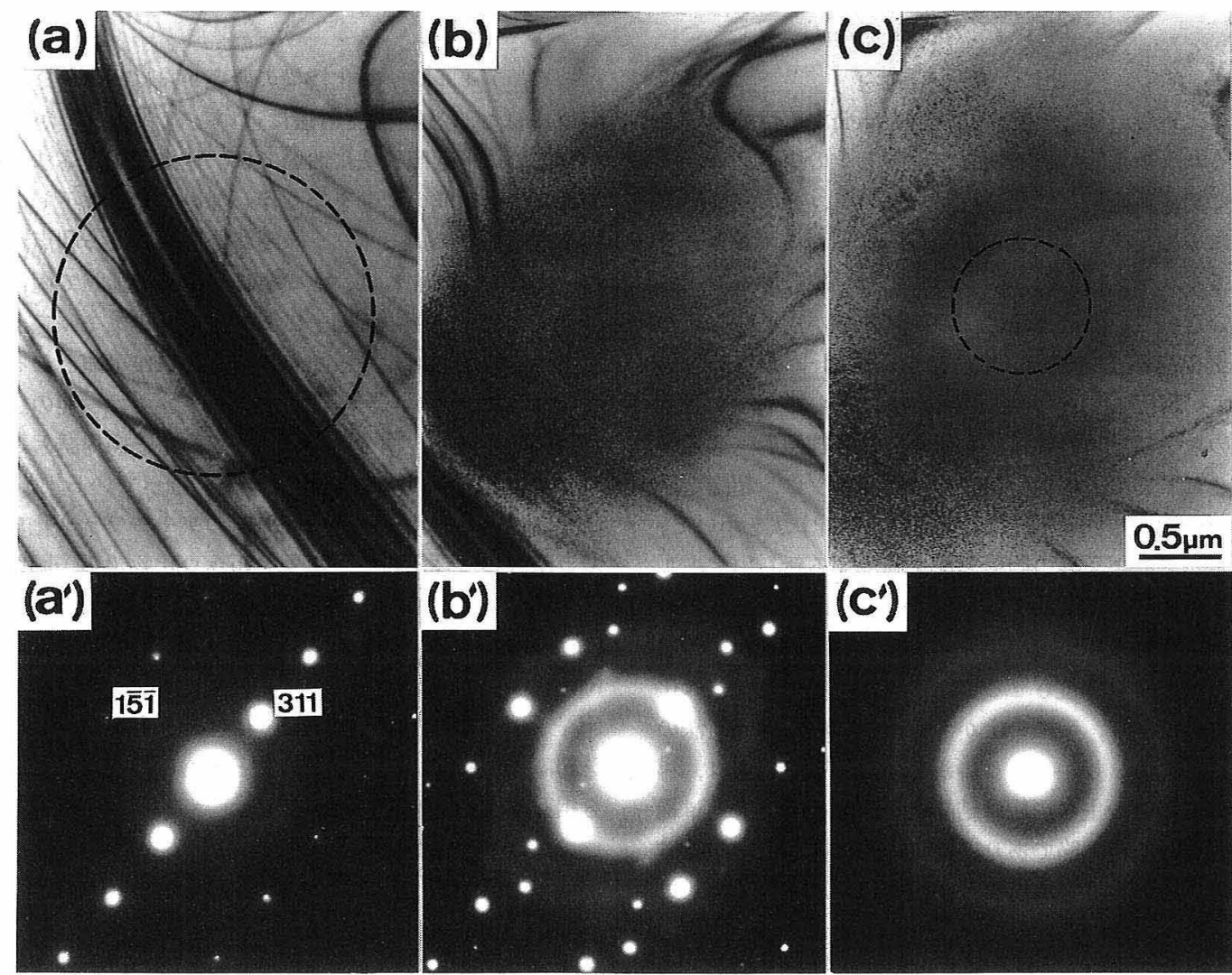

(c)

1. Successive stages of the amorphization of $\mathrm{Ni}_{2} \mathrm{~B}$ by $2 \mathrm{MeV}$ electron irradiation with correspondin diffraction patterns. Irradiation temperature $T$ and flux $\phi$ are $4.2 \mathrm{~K}$ and $1.3 \times 10^{24} \mathrm{e} / \mathrm{m}^{2} \mathrm{~s}$, respectively. (a) Before irradiation, (b) after $600 \mathrm{~s}$ irradiation, (c) after $2.4 \mathrm{ks}$ irradiation. The circle in (a) depicts the size and position of the irradiated area. 
それぞれ照射前, 600 秒および 2400 秒照射後の同一か 所の明視野像を示す。ここで図 1 (a) 中の破線は照射 領域を示している. 図 $1\left(a^{\prime}\right)$ ，(b') および $\left(c^{\prime}\right)$ は, それぞれ図 1 (a)，(b) および (c) に対応する制限視 野回折図形であり，照射領域の中央部（一例を図 1 (c) に破線の円で示す) に制限視野絞りをセットして撮られ たものである．照射を開始すると，図 1 (b) に示すよ うに, 照射領域内の等傾角消衰縞 (bend contour) は次 第にコントラストを失いはじめ, 照射量の増加とともに, この現象は徐々に進行する. そして最終的には図 1 (c) に示すように照射領域から等傾角消哀縞をはじめすべて のブラッグ反射のコントラストが消滅するに至る。これ に対応して，回折図形においては，照射の初期にアモル ファス特有のハローリングが $\mathrm{Ni}_{2} \mathrm{~B}$ の網状スポット図形 に重盢して現れる（図1 $\left(b^{\prime}\right)$ ). その後, 照射の進行亡 共に $\mathrm{Ni}_{2} \mathrm{~B}$ の回折班点ならびにハローリングの強度はそ れぞれ消衰ならびに増大を続け，最終的にはすべての回 折斑点が消滅してハロー図形に変化する(図 $\left.1\left(c^{\prime}\right)\right)$. 以上の観察結果から， $\mathrm{Ni}_{2} \mathrm{~B}$ 化合物は 2400 秒程度の照射 によって完全にアモルファス化すると結論される，o-
$\mathrm{Ni}_{4} \mathrm{~B}_{3}$ においても同様な結晶-アモルファス遷移が観察 された。

\section{$3.2 \mathrm{~m}-\mathrm{Ni}_{4} \mathrm{~B}_{3}$ ならびに NiB の照射損傷挙動}

$\mathrm{m}-\mathrm{Ni}_{4} \mathrm{~B}_{3}$ の照射損傷挙動を図 2 に示す. 図 2 (a) （c) は，それぞれ照射前， 2700 秒および 10800 秒照射後の 同一か所の明視野像であり，図 2 (a) 中の破線は照射 領域を示す. 図 $2\left(a^{\prime}\right)$ ( $\left.c^{\prime}\right)$ は, それぞれそれらに対 応する電子回折図形であり，いずれも図 1 の場合と同様 に照射領域の中央部に制限視野絞りをセットして撮影さ れたものである.図 2 の明視野像から明らかなように, 照射にともなってまず無数の black spot defects が形成 され（図2 (b))，それらは照射の進行と共に成長する (図 2 (c)). 一方, 回折図形においては, 照射の進行 と共にハローリングが出現しはじめ（図 $\left.2\left(b^{\prime}\right)\right)$ ，その 強度は徐々に増大する（図 $\left.2\left(c^{\prime}\right)\right)$ 。しかし，10秒以上 の重照射を施したこの時点においてもなおその強度は低 く, 当初から存在する $\mathrm{m}-\mathrm{Ni}_{4} \mathrm{~B}_{3}$ の $(\overline{1} \overline{11} 6)$ 回折図形の 方が高次の回折班点の強度は全般に低下しているものの むしろ優勢である（図 $\left.2\left(c^{\prime}\right)\right)$. 以上の観察から，m$\mathrm{Ni}_{4} \mathrm{~B}_{3}$ 化合物は $10^{4}$ 秒を越える長時間の照射によっても

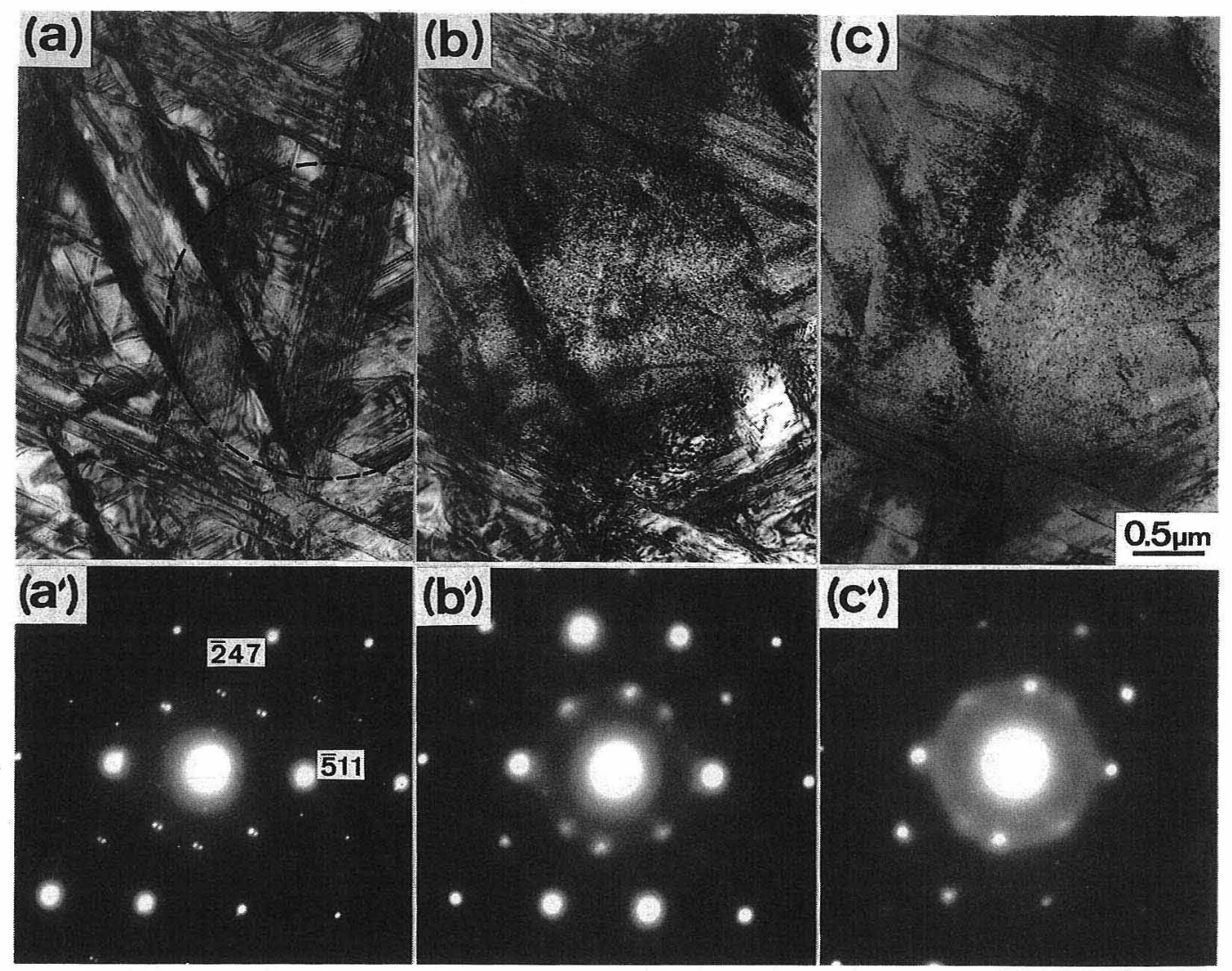

Fig. 2. In-situ irradiation sequence showing defect agg regation and partial amorphization in $m-\mathrm{Ni}_{4} \mathrm{~B}_{3}$. $E=2 \mathrm{MeV}, T=4.2 \mathrm{~K}, \phi=1.3 \times 10^{24} \mathrm{e} / \mathrm{m}^{2} \mathrm{~s}$. (a) Before irradiation, (b) after $2.7 \mathrm{ks}$ irradiation, (c) after $10.8 \mathrm{ks}$ irradiation. 
完全にはアモルファス化せず，結晶状態が高い安定度を 有することがわかる，なお，ここで形成される black spot defects の本性については現在別途に研究中であ り，それらが微小なアモルファスゾーンであるのか，転 位ループであるのか，あるいはその他の 2 次欠陥である のかについては未だ結論を得ていない.

$\mathrm{NiB}$ についてもほぼ同様な損傷挙動が観察された。

\section{3 $\mathrm{Ni}_{3} \mathrm{~B} ， \mathrm{Ni}$ および $\mathrm{B}$ における照射損傷挙動}

$\mathrm{Ni}_{3} \mathrm{~B}$ の損傷挙動を図 3 に示す。図 $3(\mathrm{a}) \sim(\mathrm{c})$ およ び $\left(a^{\prime}\right) \sim\left(c^{\prime}\right)$ は，それぞれ照射前，1800 秒， 3600 秒 照赦後の明視野像およびそれらに対応した制限視野回折 図形を示す．図 3 (a) 中の破線で描かれた円は照射領 域の位置と大きさを示している.図 3 から明らかなよう に，照射によって高密度の微小な 2 次欠陥が形成される ものの (図 3 (b), (c)), 回折図形には変化はなく(図 3 $\left.\left(b^{\prime}\right),\left(c^{\prime}\right)\right)$, 結晶一アモルファス遷移の兆候は全く認 められない.

純物質の $\mathrm{Ni}$ と $\mathrm{B}^{8)}$ においてもアモルファス化の兆候 は全く認められない,

\section{4. 考 察}

今回の実験によってニッケルホウ化物の中で $\mathrm{Ni}_{2} \mathrm{~B}$ と o- $\mathrm{Ni}_{4} \mathrm{~B}_{3}$ の二種類の化合物が電子照射によって完全にア モルファス化することが明らかになった．著者らのグ ループではさきに $\mathrm{B}_{4} \mathrm{C}$ 化合物が電子照射によって同様 にアモルファス化することを明らかにしており ${ }^{8)}$ ，今回 の実験および Mogro-Campero らによる $\mathrm{Fe}_{3} \mathrm{~B}$ の結果 ${ }^{9}$ と総合すると，高エネルギー電子線の照射によって誘起 される結晶-アモルファス遷移は，金属元素同士の金属 間化合物")のみならず，遷移金属ホウ化物を含むホウ化 物セラミックスにおいても生じる普遍性の高い現象であ ることがわかる。

次に $\mathrm{Ni}-\mathrm{B}$ 二元系に存在する合計 7 種類の相の中で $\mathrm{Ni}_{2} \mathrm{~B}$ とo- $\mathrm{Ni}_{4} \mathrm{~B}_{3}$ だけがアモルファス化する，換言すれ ば強いアモルファス形成傾向を示す点について考察を加 える.これは，各相のアモルファス形成傾向がどのよう なパラメーターによって左右されているのかを明らかに することが,アモルファス形成の一般法則を導く上での 緛口となるためである．緒言にも述べたように，粒子線 照射によって結晶をアモルファス化する手法は主にイオ
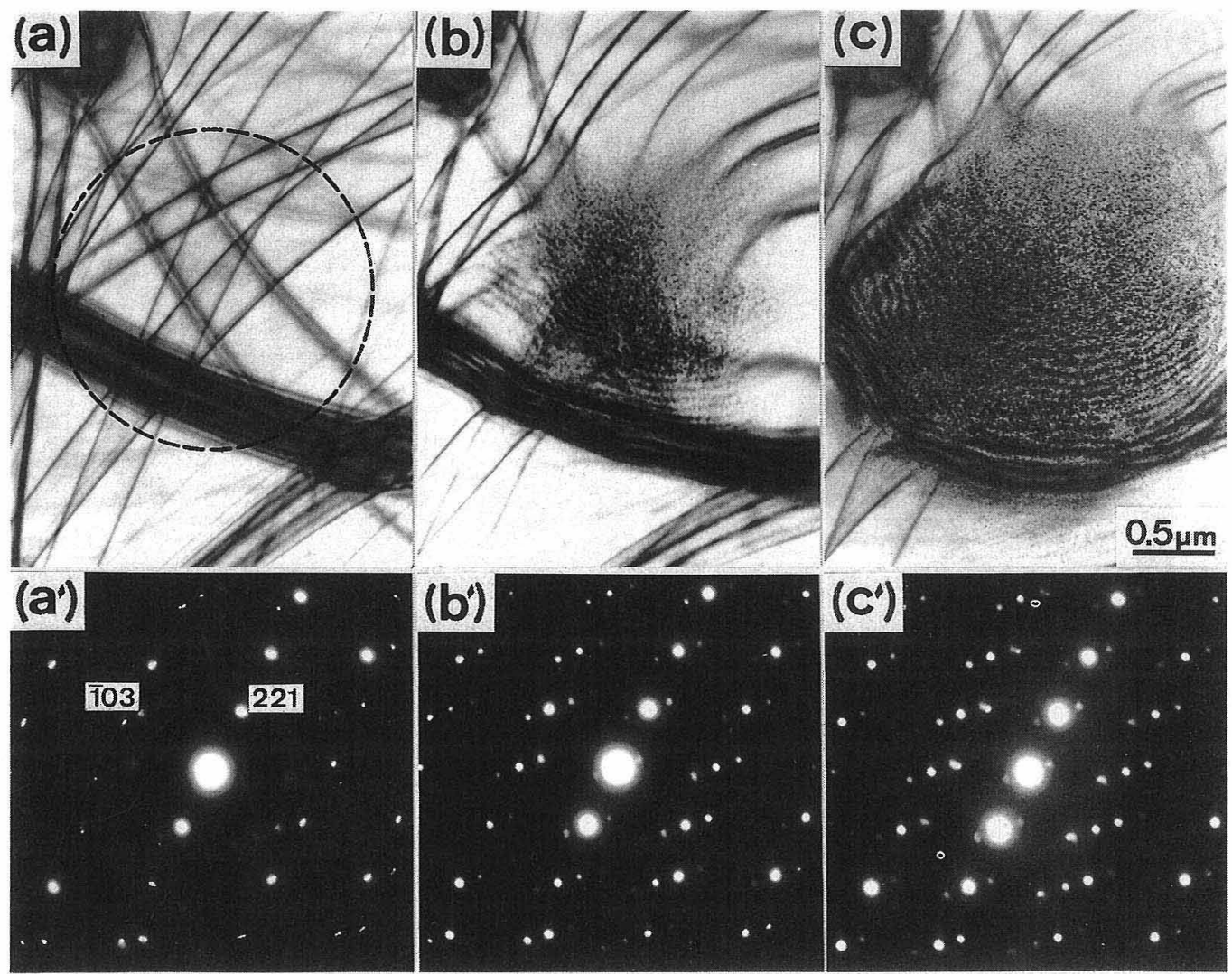

Fig. 3. In-situ irradiation sequence showing defect aggregation in $\mathrm{Ni}_{3} \mathrm{~B}$. $E=2 \mathrm{MeV}, T=4.2 \mathrm{~K}, \phi=1.3 \times 10^{24} \mathrm{e} / \mathrm{m}^{2} \mathrm{~s}$. (a) Before irradiation, (b) and (c) after $1.8 \mathrm{ks}$ and $5.4 \mathrm{ks}$ irradiation, respectively. 
Table 1. Crystal stability under electron irradiation of all phases in the $\mathrm{Ni}-\mathrm{B}$ binary system. Various physical parameters for the phases are also included.

\begin{tabular}{|c|c|c|c|c|c|}
\hline compound & responce & $\begin{array}{l}\text { crystal } \\
\text { system }\end{array}$ & $\begin{array}{l}\text { crystal } \\
\text { structure }\end{array}$ & $\begin{array}{l}\mathrm{n} / \text { unit } \\
\text { cell }\end{array}$ & $\begin{array}{l}\text { extent of } \\
\text { solubility (at\%) }\end{array}$ \\
\hline $\mathrm{Ni}$ & $x$ & cubic & Al & 4 & none \\
\hline $\mathrm{Ni} 3 \mathrm{~B}$ & $x$ & $\begin{array}{l}\text { ortho- } \\
\text { rhombic }\end{array}$ & DO॥I & 16 & none \\
\hline $\mathrm{Ni} 2 \mathrm{~B}$ & 0 & tetragonal & $\mathrm{Cl} 6$ & 12 & none \\
\hline $\mathrm{O}-\mathrm{Ni}_{4} \mathrm{~B}_{3}$ & 0 & $\begin{array}{c}\text { ortho- } \\
\text { rhombic }\end{array}$ & $\mathrm{D} 2 \mathrm{~h}^{16}$ & 28 & none \\
\hline $\mathrm{m}-\mathrm{Ni}_{4} \mathrm{~B}_{3}$ & $x$ & monoclinic & $\mathrm{C}_{2 n^{6}}$ & 28 & none \\
\hline $\mathrm{NiB}$ & $x$ & $\begin{array}{c}\text { ortho- } \\
\text { rhombic }\end{array}$ & $B f$ & 8 & none \\
\hline B & $x$ & hexagonal & $D_{3 d^{5}}$ & 324 & none \\
\hline
\end{tabular}

ン照射によって開発，発展させられてきた経緯がある関 係上，イオン照射による結晶のアモルファス化の難易に 対してはこれまでにいくつかの判断基準 (criterion) が 提唱されている.ここではまずそれらの判断基準がニッ ケルホウ化物の電子線照射の場合にも適用できるか否か を検証したあとで，新しい基準を提案する．この考察に 資する目的で各相の諸物性を，アモルファス化の有（完 全にアモルファス化するものを有とし，○印）無（×印） と共に表 1 にまとめて示す.

Matzke とWhitton は一連の非金属化合物のイオン照 射実験を行い, 対称性の悪い結晶ほよ゙アモルファス化し やすく，対称性のよい例えば立方晶結晶はアモルファス 化しにくいという，いわゆる structure-type criterion を 提案している ${ }^{10)}$. 表 1 の第 3 列目はこの基準を調べるた めに各相の結晶系を示したものである。実験結果は, 例 えば対称性の高い $\mathrm{Ni}_{2} \mathrm{~B}$ がアモルファス化する一方で, より対称性の低い $\mathrm{Ni}_{3} \mathrm{~B}$ や $\mathrm{m} \cdot \mathrm{Ni}_{4} \mathrm{~B}_{3}$ が結晶を保つことを 示しており，この基準は電子照射によるアモルファス化 に対しては成立しないことがわかる.

表 1 の第 4 列目並びに第 5 列目は，それぞれ結晶構造 (あるいは空間群) 並びに単位胞当たりの原子の数を示 したものである.これらはいずれも結晶構造の複雑さを 表すパラメーターと考えられる. Takayama らは，イオ ン照射法の場合も含めて, 一般的に結晶構造の複雑な化 合物はアモルファス化しやすいとしている ${ }^{11)}$. しかし, 今回調べた 7 種類の相の中で $\mathrm{Ni} \zeta$ - $\mathrm{CrB}$ 構造の $\mathrm{NiB}$ 以外はいずれも単位胞中に 10 個以上の原子を含む複雑 な構造をとっており，アモルファス化した $\mathrm{Ni}_{2} \mathrm{~B}$ と。
$\mathrm{Ni}_{4} \mathrm{~B}_{3}$ だけが特に複雑な構造を有しているわけではな い、このことから, 結晶構造の複雑さという観点に基づ いてアモルファス化傾向を予言することは困難であると 考えられる.

最近, Brimhall らは, 状態図上で固溶範囲の小さな 金属間化合物ほよ゙イオン照射によって容易にアモルファ ス化するという solubility criterion を提案している ${ }^{12}$. この基準を検討する目的で表 1 の第 6 列目には各相の固 溶範囲の大きさをあげたが，いずれの相も固溶範囲はほ とんゼなく、この基準によって今回観察されたアモル ファス化の難易を分類することは困難である．

以上のほかに, Naguib と Kelly は, 非金属化合物の 場合，イオン化度が 0.47 以下の化合物ならばイオン照 射によってアモルファス化するという bond-type criterion ${ }^{13)}$ を，またGiessen は液体急冷法によってアモ ルファスを得るためには構成原子の半径比は 1.25 以上 でなければならないとする判断基準 ${ }^{14)}$ を，それぞれ提案 している。しかし，これらのパラメーターは，系を決め れば一義的に決まるパラメーターであり（例えば Ni-B 系の場合イオン化度は 0.01 , 原子半径比は 1.42 と定ま る), これらだけによって一つの系に存在する化合物の 間のアモルファス化傾向の相違を予言することは本質的 に不可能である.このように，今回の観祭結果はこれま でに提案されている判断基準によっては整理することが 困難である。ところで，アモルファス合金作製法として 現在最も一般的に用いられている液体急冷法において は, 温度一組成平衡状態図の形状がアモルファス形成能 に対する有用な情報を与えることが知られている(5),16). 


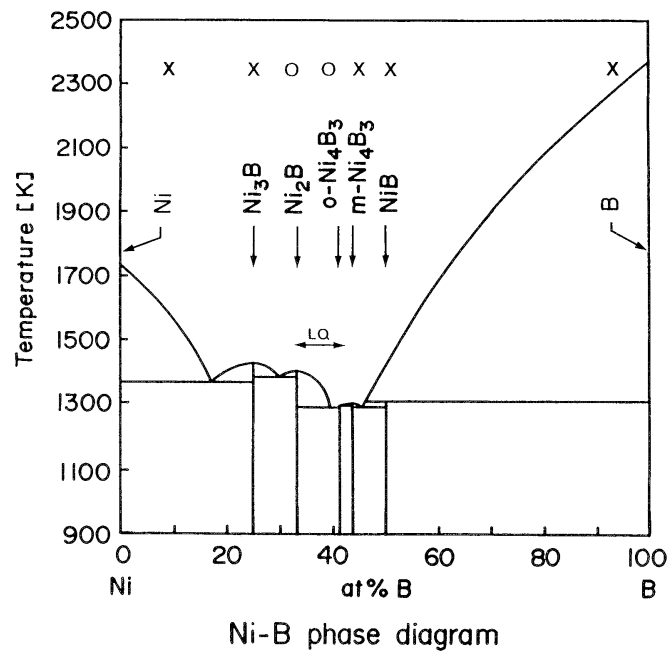

Fig. 4. Ni-B phase diagram. Marks $\bigcirc$ and $\times$ labelled on each phase represent the presence and absence of the crystalline to amorphous transition induced by electron irradiation, respectively. The composition range over which amorphous materials can successfully be obtained by rapid liquid quenching is indicated (L.Q.).

すなわち，共晶組成近傍の合金は大きなアモルファス形 成能を持つことが報告されている.これを参考にして, ニッケルホウ化物の電子照射誘起アモルファス化傾向を 平衡状態図上で検討した結果を図 4 に示す。この図で相 の名前に付した○および×印は,アモルファス化の有(表 1 の定義による) および無を示す. 図 4 からわかるよう に，アモルファス化する $\mathrm{Ni}_{2} \mathrm{~B}$ とo- $\mathrm{Ni}_{4} \mathrm{~B}_{3}$ の 2 個の化合 物はいずれも，B および $\mathrm{Ni}$ の融点から大きく低下する 2 本の液相線が形作る液相の深い谷の近傍に位置してお り, それらの化合物の組成は液体急冷法によってアモル ファスが形成される組成範囲 $(\mathrm{L} Q)^{17)}$ に含まれている.

同様の相関は,これまでにアルミニウム-遷移金属の二 元系および遷移金属同士の二元系においても認められて おり ${ }^{7)}$, 今回の結果はこうした相関が金属元素同士の化 合物に限らず，ホウ化物を含む広範囲の化合物にわたっ てみられる一般性の高いものであることを示している.

従来, 液体急冷法によって共晶組成近傍の合金がアモル ファス化しやすい理由は, (1)融点とガラス遷移点との温 度差が小さい上に ${ }^{18)}$, (2)結晶状態にある非平衡単相への 遷移が困難なため, 結晶化に際して相分離を起こすこと が必要となるが，そのための原子の長距離拡散に要する 時間が結晶核の形成を遅らせることによる ${ }^{15)}$ ，とされて いる. しかし, 今回のように, 液体の急冷という過程を 全く含まない手法, すなわち電子線照射による原子のは じき出し損傷の導入・蓄積という手法によって形成され るアモルファスもまた, 液相が深い谷を形作る組成範囲 に位置する化合物で優先的に生成される事実は, 上述の
(1)や(2)の因子がこの組成範囲の合金が持つ強いアモル ファス形成能力の本質的な原因ではないことを示してい る. この点に関連して著者の一人は構成原子の間にどれ ほど多様な配置が許されるかという配置の多様性こそが アモルファス形成傾向を左右する本質的な因子であると するモデルを提案している ${ }^{5)}$ が, 今回の実験結果も, 表 1 にあげたようなパラメーターによってではなく，むし ろこのような観点からの整理が必要であると考えられ る.この整理の結果については稿を改めて報告する.

\section{5. 結 言}

ホウ化物セラミックスのアモルファス化に関する研究 の一環として, ニッケルホウ化物の電子照射誘起による 結晶-アモルファス遷移を調べた. すなわち, $\mathrm{Ni}-\mathrm{B}$ 二元 系に存在するすべての化合物 $\left(\mathrm{Ni}_{3} \mathrm{~B}, \mathrm{Ni}_{2} \mathrm{~B}, \mathrm{o}-\mathrm{Ni}_{4} \mathrm{~B}_{3}\right.$, $\mathrm{m}-\mathrm{Ni}_{4} \mathrm{~B}_{3}$ および $\mathrm{NiB}$ の 5 個の化合物）ならびに純物質 の $\mathrm{Ni}$ と B を試料として選び, これら 7 種類の相の電子 線照射によるアモルファス化能を超高圧電顕法によって 調べた. 得られた結果は以下のように要約される.

（1）加速電圧 $2 \mathrm{MV}$, 照射温度 $4.2 \mathrm{~K}$, 電子線強度 $1.3 \times 10^{24} \mathrm{e} / \mathrm{m}^{2} \mathrm{~s}$ の一定条件下で, $\mathrm{Ni}_{2} \mathrm{~B}$ と $-\mathrm{Ni}_{4} \mathrm{~B}_{3}$ は約 2400 秒の照射によって完全にアモルファス化する. 一 方, $\mathrm{m}-\mathrm{Ni}_{4} \mathrm{~B}_{3}$ と $\mathrm{NiB}$ では回折図形にアモルファスの存 在を示すハローリングが現れるものの，その強度は $10^{4}$ 秒以上の重照射後もなお微弱であり, 完全なアモルファ ス化は生じない。 $\mathrm{Ni}_{3} \mathrm{~B}$ ならびに純物質の $\mathrm{Ni}$ と $\mathrm{B}$ は結 晶を保つ.

(2) 7 種類の相の中で $\mathrm{Ni}_{2} \mathrm{~B}$ と $\mathrm{o}-\mathrm{Ni}_{4} \mathrm{~B}_{3}$ だけが強い アモルファス形成傾向を示す理由は, 従来からイオン照 射誘起による結晶-アモルファス遷移の難易を分類する ために用いられてきた結晶系, 結晶構造, 単位胞内の原 子数, 固溶度, 原子半径比, イオン化度などのパラメー ターでは整理できない。

（3）電子照射誘起アモルファス化の難易はむしろ平 衡状態図上での当該化合物の存在位置と強い相関が認め られる。

\section{文献}

1) H. Mori and H. Fujita, Jpn. J.Appl. Phys., 21, L 494-96 (1982).

2) G. Thomas et al., Scripta Met., 16, 589-92 (1982).

3) H. Mori, H. Fujita and M. Fujita, Jpn. J. Appl. Phys., 22, L94-96 (1983).

4) H. Fujita, H. Mori and M. Fujita, Proc. 7th Int. Conf. on HVEM, Lawrence Berkeley Lab., Univ. of California, Berkeley (1983) pp. 233-38.

5) H. Fujita, J. Electron Microscopy Tech. , 3, 45-56 (1986).

6) P. Ziemann, Mat. Sci. and Eng., 69, 95-103 (1985).

7) H. Mori and H. Fujita, Proc. 5th Japan Inst. Metals Int. Symp. on Non-equilibrium Solid Phases of Metals and Alloys, Japan Inst. Metals, Sendai (1988) pp. 93-96. 
8) H. Inui, H. Mori and H. Fujita, Scripta Met., 22, 249-54 (1988).

9) A. Mogro-Campero et al., Metastable Materials Formation by Ion-Implantation, N-H, New York (1982) pp. 203-10.

10) Hj. Matzke and J.L. Whitton, Can. J. Phys., 44, 995-1010 (1966).

11) S. Takayama, J. Mater. Sci., 11, 164-85 (1976).

12) J.L. Brimhall, H. E. Kissinger and L. A. Charlat, Rad Eff., 77, 237-93 (1983).

13) H. M. Naguib and R. Kelly, Rad. Eff., 25, 1-12 (1975).
14) B. C. Giessen, Proc. 4th Int. Conf. on Rapidly Quenched Metals, Eds. T. Masumoto and K. Suzuki, Sendai (1981) pp. 213-16.

15) T. B. Massalski, Proc. 4th Int. Conf. on Rapidly Quenched Metals, Sendai (1981) pp. 203-08.

16) D. E. Polk and B.C. Giessen, Metallic Glass, American Society for Metals (1978) pp. 1-35.

17) A. Inoue, A. Kitamura and T. Masumoto, Trans. JIM, 20, 404-06 (1979)

18) N.E. Cusack, The Physics of structurally disordered matter, Adam Hilger, Bristol (1987) pp.360-94. 